\title{
Nilai-nilai Pendidikan Optimisme pada Tradisi Tedhak siten di Masyarakat Jawa
}

\section{Optimism Educational Values in the Tedhak Siten Tradition in Javanese Society}

\author{
Anwar Hafidzi* \\ Fakultas Syariah, Universitas Islam Negeri Antasari \\ Jalan Ahmad Yani, Km.4.5 Banjarmasin, Indonesia \\ Diterima: 15 September 2020; Direview: 26 September 2020; Disetujui: 14 Oktober 2020
}

*Coresponding Email: anwar.hafidzi@uin-antasari.ac.id

\begin{abstract}
Abstrak
Penelitian ini bertujuan untuk mengungkap makna dibalik tradisi tedhak siten dan hubungannya dengan perubahan dan struktur kehidupan di masyarakat. Meskipun penelitian ini banyak yang membahas dari nilai filosofinya, namun nilai karakter belum ada yang membahasnya. Temuan ini setidaknya membuktikan bahwa tradisi dapat memberikan nilai positif dalam kehidupan bermasyarakat. Penelitian ini menggunakan penelitian deskriptif-kualitatif dengan data primer peneliti dapatkan dari wawancara dan observasi saat prosesi upacara tedhak siten di daerah Tanah Laut, Kalimantan Selatan. Hasil penelitian ini membuktikan bahwa tradisi tedhak siten yang dilakukan oleh masyarakat Jawa masih mengadopsi ajaran Islam. Upacara tersebut memiliki makna yang berkaitan dengan pembentukan karakter anak, perubahan sikap dan diri dalam kehidupan di masyarakat pada masa akan datang. Tradisi ini cenderung memunculkan nilai-nilai kebaikan berupa pola sedekah, bersyukur, berdoa, dan penuh harap. Teori ini cenderung disebut dengan Pendidikan optimisme terhadap apa yang akan dan dicapai nantinya.
\end{abstract}

Kata Kunci: Tradisi; Tedhak Siten; Masyarakat;

\begin{abstract}
This study aims to uncover the meaning behind the tedhak siten tradition and its relationship to the changes and structure of life in society. Although there are many studies that discuss this from its philosophical values, there is no character value that discusses it. These findings at least prove that tradition can provide a positive value in social life. This study uses descriptive-qualitative research with primary data researchers obtained from interviews and observations during the procession of Tedhak siten ceremony in Tanah Laut, South Kalimantan. The results of this study prove that the tedhak siten tradition practiced by the Javanese people still adopts Islamic teachings. The ceremony has a meaning related to the formation of the child's character, changes in attitude and self in life in society in the future. This tradition tends to bring up the values of goodness in the form of patterns of alms, giving thanks, praying, and being hopeful. This theory tends to be called Education optimism about what will and will be achieved later.
\end{abstract}

Keywords: Tradition; Tedhak Siten; Public;

How to Cite: Hafidzi, A. (2020). Nilai-nilai Pendidikan Optimisme pada Tradisi Tedhak siten di Masyarakat Jawa, Journal of Education, Humaniora and Social Sciences (JEHSS). 3 (2): 442-451. 


\section{PENDAHULUAN}

Indonesia disebut juga dengan negara kepulauan yang terdiri dari beberapa pulau yang ada di Indonesia dan memiliki berbagai macam suku bangsa, bahasa, adat istiadat atau yang sering kita sebut dengan kebudayaan (Daud, 2000). Keanekaragaman budaya yang berada di Indonesia merupakan suatu bukti jika Indonesia adalah negara yang kaya akan budaya (Humaidi, 2016). Agama Islam mengajarkan agar para pemeluknya melakukan kegiatan-kegiatan positif yang berkaitan dengan ibadah (Nugroho \& Wahid, 2019). Bagi kebanyakan masyarakat Jawa (Simanjuntak, 2016), dalam kehidupan selalu saja penuh dengan sebuah upacara, baik yang berkaitan langsung dengan lingkungan hidup seorang manusia sejak dari dalam kandungannya, ketika kelahiran, saat kanakkanak, hingga dewasa sampai dengan kematiannya. Juga upacara-upacara yang berkaitan dengan aktivitas kehidupan sehari-hari seperti nafkah dan ritual keagamaan lainnya, masuk dalam pendidikan dan pembudayaan (Suharyanto, 2015).

Tedhak siten (Batubara, 2017) merupakan dari budaya dan adat istiadat masyarakat Jawa, dan upacara ini dilakukan bagi anak yang pertama kali belajar berjalan atau pertama kali menginjakkan kaki di tanah atau bumi dan ditunggu-tunggu oleh orang tua. Upacara ini dilakukan ketika seorang anak berusia pitung lapan (7 x 35 hari) 245 hari atau setara dengan 6 bulan dan mulai belajar berjalan, yang mana dengan upacara ini bertujuan agar sang anak menjadi orang yang mandiri dimasa depan kelak (Devi \& Desain, n.d.). Tedhak siten memiliki arti kata Tedhak yang berarti menapakkan kaki, dan Siten berasal dari kata siti yang berarti tanah atau bumi (Djaya, 2020). Pada upacara adat yang dilakukan oleh masyarakat Jawa yaitu dengan mengarahkan anak untuk menginjakkan kaki di jaddah (ketan) 7 warna kemudian anak dibimbing untuk menaiki anak tangga yang terbuat dari tebu wulung (tebu merah) dan berdiri di atas pasir hingga rentetan upacara lainnya selesai. Selanjutnya, anak dimasukkan ke dalam kurungan (sangkar) yang didalamnya sudah terdapat bermacam-macam barang (tiruan) dari alatalat tulis, alat music, alat kedokteran dan lain sebagainya. Kemudian anak dibimbing untuk mengambil salah satu dari barang yang disediakan dalam kurungan dengan harapan "Barang yang diambil anak tersebut sebagai wujud gambaran apa yang digemari anak ketika di kemudian hari dan semua itu juga tak lepas dari doa dan restu dari kedua orang tuanya" (Mursalim, 2019).

Banyak alasan yang menyebabkan tradisi Tedhak siten semakin terlupakan di Indonesia. Salah satu alasan penyebab hilangnya tradisi Tedhak siten adalah karena masyarakat yang sudah tidak perduli lagi dengan tradisi tersebut, dan dengan adanya kemajuan teknologi yang berkembang pesat di Indonesia maka tradisi tedhak siten pun terlupakan (Anggraini, Sinaga, \& Wakidi, 2016). Sistem pendidikan yang berkembang pesat di masyarakat, menjadikan perubahan pola pikir yang membuat masyarakat berasumsi bahwa tradisi tersebut sudah tidak efektif dan efisien untuk dilaksanakan dalam kehidupan (Lubis, n.d.).

Pelaksanaan Tedhak siten ini dianggap wajib dilaksanakan bagi masyarakat Jawa, karena jika tidak melaksanakan Tedhak siten maka sang buah hati (anak) akan menjadi manja dan selalu bergantung kepada orang tua kelak hingga dewasa, selain itu upacara ini juga berguna sebagai acuan pengembangan potensi bagi masyarakat Jawa (Probowardhani \& Sri Arfiah, 2016). Pelaksanaan Tedhak siten akan terlihat nyata

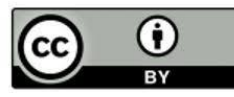


karena turut mengundang para tetangga, sanak keluarga, teman, kerabat maupun sahabat.

Pada dasarnya pelaksanaan upacara Tedhak siten pada masyarakat Jawa dilakukan secara turun-temurun, walau terkadang sebagian masyarakat ada yang tidak mengetahui akan nilai yang terkandung dalam tradisi upacara itu sendiri (Violetta Yuvinda Putri, 2017). Upacara Tedhak siten memanglah masih dilaksanakan pada masyarakat Jawa, namun dengan seiring berjalannya waktu maka pelaksanaan upacara ini disesuaikan dengan kondisi lingkungan sekitar, selain itu kebanyakan masyarakat yang melaksanakan upacara ini hanya mengetahui makna secara umum tentang apa itu pelaksanaan Tedhak siten saja dan tidak mengetahui nilai-nilai apa saja yang terkandung di dalam setiap prosesnya (Fathurrozaq, 2019).

Rasulullah SAW mengajarkan pada pengikutnya untuk terus mengamalkan ajaran Islam yang telah di bawa olehnya. Sikap yang harus ditunjukkan oleh seorang hamba Allah -manakala telah meyakini nilai-nilai Islam sebagai ajaran yang benar- ialah mewujudkannya dalam kehidupan sehari-hari (Mokodenseho \& Wekke, 2017). Keyakinan yang tidak diajarkan dalam Islam dan bertentangan haruslah segera di tinggalkan, sebab pada diri seorang muslim haruslah menegakkan tauhid dan memberantas kesyirikan, serta menghidupkan sunnah dan meninggalkan bid'ah. Yang mana terdapat dalam Q.S al-Hasyr ayat 7

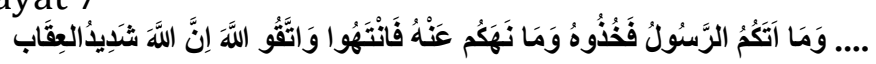

"Apa yang diberikan Rasul kepadamu, maka terimalah. Dan apa yang dilarangnya bagimu, maka tinggalkanlah. Dan bertakwalah kepada Allah. Sesungguhnya Allah sangat keras hukum-Nya."

Demikian pula dalam menyikapi berbagai macam tradisi yang berkembang di masyarakat, (Schlehe, 2010) terkhusus tradisi yang menyangkut pada kelahiran. Semuanya tentu harus dikembalikan kepada ajaran Islam. Pelaksanaan kenduri, upacara dan proses lainnya yang telah turun temurun itu tidak bertentangan dengan Islam dan perkara bebasnya segenap tradisi dari keyakinan-keyakinan kesyirikan, kebid'ahan dan hal yang bisa memudharatkan. Islam disebut juga sebagai agama yang sempurna, karena ajaran dalam Islam meliputi semua sisi kehidupan dalam masyarakat, yang mana Islam mengatur beberapa masalah berupa kelahiran, kematian, pernikahan, perceraian, mengasuh anak, menyusun kehidupan rumah tangga, saat jual beli, hingga urusan pemerintahan (Hafidzi \& Hayatunnisa, 2018). Di antara sifat syariat Islam ialah mudah untuk ditunaikan oleh pemeluknya. Tidak mempersulit dan membuat riweh. Simple, praktis dan terasa meringankan, tidak memberatkan, seperti Sabda Rasulullah Saw yang maknanya berbunyi: "Permudahlah, jangan kalian persulit. Senangkanlah, jangan kalian (menjadikannya) lari menjauh" (HR. al-Bukhari no 69).

Berdasarkan paparan tersebut, maka tujuan dari penelitian ini setidaknya dapat menjawab latar kegiatan praktik tedhak siten dan untuk melihat nilai Pendidikan karakter yang tersirat dari berbagai kegiatan tradisi tersebut.

\section{METODE PENELITIAN}

Pendekatan dalam penelitian ini adalah penelitian kualitatif, yaitu prosedur penelitian yang menghasilkan data deskriptif berupa kata-kata tertulis dari orang-orang atau perilaku yang dapat diamati. Pada penelitian ini penulis menitik beratkan pada 
"Tradisi Tedhak siten (mudun lemah) tradisi symbol awal perjalanan hidup seseorang dalam masyarakat Jawa di Kabupaten Tanah Laut"

Jenis penelitian ini adalah Field Research (Penelitian Lapangan) yaitu suatu penelitian yang menggunakan informasi atau responden melalui instrumen pengumpulan data seperti wawancara dan sebagainya. Penelitian ini dilakukan di Desa Gunung Mas Kecamatan Batu Ampar Kabupaten Tanah Laut, dengan melihat keadaan lapangan apa adanya, dengan melakukan wawancara dengan pihak-pihak yang terkait dalam pelaksanaan penelitian di Desa Gunung Mas.

Sumber data utama penelitian ini didapat dari responden dengan wawancara mendalam dan sumber sekunder yang mendukung penelitian ini dari beberapa jurnal dan buku yang membahas tentang tradisi, tedhak siten, dan pendidikan. Observasi tradisi tedhak siten selama satu bulan pada Juli 2019 ketika tradisi itu dilakukan.-Sumber wawancara didapat melalui beberapa responden yaitu tokoh masyarakat, yaitu Mulyati, H. Suparman dan Sukardi sebagai pelaksana tradisi yang dikerjakan setiap kelahiran anak. Teknik wawancara yang digunakan dalam penelitian ini adalah wawancara terstruktur.

Analisis data merupakan proses mencari dan menata hasil observasi, wawancara dan dokumentasi secara sistematis untuk meningkatkan pemahaman peneliti tentang kasus yang diteliti dan menyajikannya sebagai temuan bagi yang lain. Sedangkan untuk meningkatkan pemahaman tersebut, analisis perlu dilanjutkan dengan berupaya mencari makna yang tersirat dari kegiatan tedhak siten. Dalam penelitian ini, penulis menggunakan metode analisis kualitatif yaitu, data yang berupa informasi, uraian dalam bentuk bahasa prosa kemudian dikaitkan dengan data yang lainnya untuk mendapatkan kejelasan terhadap suatu kebenaran. Teknik ini digunakan untuk mendeskripsikan dan menginterpretasikan makna tradisi Tradisi Tedhak siten (mudun lemah) tradisi symbol awal perjalanan hidup seseorang dalam masyarakat Jawa di Kabupaten Tanah Laut. Lama penelitian ini dimulai dari bulan Juli hingga September 2019

\section{HASIL DAN PEMBAHASAN \\ Pola dan Praktik Tedhak siten}

Tedhak siten berasal dari kata tedhak dan siten. Tedhak artinya turun sedang siten berarti tanah. Dengan demikian maksud dari pada upacara tedhak siten adalah upacara turun tanah (Djaya, 2020). Tedhak siten merupakan upacara pada seorang anak yang telah lahir dan mencapai umur pitung lapan atau setara dengan 6 bulan kalender Masehi, yang mana pada dasarnya anak sudah mulai belajar untuk berjalan, si anak sudah mulai di ajari atau di tuntun menggunakan kakinya untuk berjalan. Artinya sudah harus turun ke tanah. Turun ke tanah dalam bahasa Jawa dinamakan tedhak siti (siten). Tahapan yang dimaksud adalah bahwa manusia mempunyai beberapa tahap perkembangan diri, yaitu (Putra, 2013):

1. Tahap bayi, yang mana sangat tergantung terhadap ibu dan orang lain, bisanya hanya meminta bantuan.

2. Tahap anak muda yang mandiri, bisa melakukan sendiri.

3. Tahap dewasa, yang sudah sadar walau mandiri tetapi tidak egois dan menyadari bahwa seseorang saling bergantung dengan orang lain, tidak bisa hidup sendiri. 
Ketika seorang anak mulai belajar berjalan, dan apabila menginginkan sesuatu ia sudah bisa mengambil sendiri tanpa minta pertolongan orang lain. Pada waktu berjalan, kedua kaki sang anak menapak langsung dengan bumi, tidak lagi dalam gendongan seorang ibu. Kita hidup hingga mati berada dibumi, maka minum, rumah, kendaraan semua berasal dari bumi, maka kita perlu menghormati bumi.

Bayi lahir dengan naluri awal, naluri dasar. Apa saja yang dipegangnya akan dimasukkan ke mulutnya. Pada waktu bayi berusia 7 × 35 hari atau 245 hari, setara dengan enam bulan, insting-naluri bawaan genetiknya masih ada, akan tetapi dalam perkembangan diri berikutnya, insting bawaan akan terdorong ke dalam bawah sadarnya, tertutup oleh kegiatan-kegiatan baru. Pada saat anak berusia sekitar 6 bulan maka potensi anak dapat diketahui. Pemilihan atas beberapa benda yang terdapat didalam upacara tedhak siten meliputi: buku tulis, dompet, emas, gunting, dan lain sebaginya yang selaras dengan pengetahuan. Potensi anak akan terlihat dengan jelas, sehingga orang tua paham betul bagaimana cara untuk meningkatkan potensi anak (Probowardhani \& Sri Arfiah, 2016).

Pada dasarnya kita hidup di dunia terkurung atau terbelenggu oleh dunia. Dalam tradisi Tedhak siten watak anak akan terlihat sangat jelas dengan sendirinya bahwa ia tidak senang ketika dimasukkan kedalam kurungan dan menangis untuk meminta pertolongan pada ibunya. Seperumpamaan dengan manusia yang sadar pun ingin kembali kepada Ilahi. Baik penganut spiritual, harta, tahta ataupun ilmu pengetahuan adalah modal awal untuk membebaskan diri dari belenggu dunia. Seorang sesepuh setempat datang untuk membebaskan diri manusia dari dalam kurungan tersebut, tetapi yang diharapkan oleh manusia adalah sesepuh yang bisa memberikan pengetahuan untuk hidup sukses dalam kurungan. Jiwa yang lepas dari kurungan dunia bukan berarti melarikan diri dari dunia, melaikan nilai filosofi yang bersifat optimis terhadap kehidupan anak pada masa yang akan datang agar sukses.

\section{Pelaksanaan Upacara Tedhak siten di Desa Gunung Mas}

Upacara Tedhak siten di desa Gunung Mas biasanya diadakan karena adanya kepercayaan, sebagian orang bahwa tanah mempunyai kekuatan gaib. Adapun ketetapan hari untuk melaksanakan upacara tedhak siten sendiri biasanya dilaksanakan setelah Hari Raya Idul Fitri dan Hari Raya Idul Adha. Adapun sarana atau keperuluan yang harus disediakan dalam upacara tedhak siten ini adalah: Jambangan (bak mandi) yang diisi dengan air bunga setaman, sangkar ayam yang terbuat dari anyaman bambu, beberapa benda-benda yang telah diletakkan ke dalam kurungan diantaranya berupa alat-alat tulis dan bokor yang mana di dalamnya berisi beras kuning, tikar baru sebagai alas anak pada kurungan serta tangga yang terbuat dari tebu merah. Setelah segala rentetan untuk berjalannya upacara tersedia, maka seseorang akan memimpin upacara dan membimbing anak yang diselamati untuk menginjak-injakkan kaki kepada 7 macam warna jadah yang terbuat dari campuran beras ketan dan parutan kelapa muda. Jadah diberi perwarna merah, putih, hitam, kuning, jingga, biru dan ungu. Kemudian anak tersebut dibimbing untuk menaiki tangga kecil yang terbuat dari tebu merah, yang terdiri dari 7 buah anak tangga. Setelah itu anak dimasukkan ke dalam sangkar ayam yang telah disediakan berbagai macam barang seperti padi, kapas, alat-alat tulis serta bokor yang berisi beras kuning dan uang logam. 
Di dalam kurungan itu, kemudian anak dibantu untuk memegang atau memilih salah satu barang-barang yang telah disediakan. Pada saat itu orang-orang yang hadir untuk mengikuti jalannya upacara tersebut memperhatikan benda apa yang akan diambil oleh anak, menurut kepercayaan benda yang diambil oleh anak tersebut ialah melambangkan mata pencahariannya atau nasib anak di kemudian hari. Misalnya, apabila anak mengambil alat-alat tulis, maka menurut kepercayaan anak tersebut kelak akan menjadi anak yang sangat cerdas. Kemudian uang dan beras kuning yang diletakkan di dalam wadah kecil akan ditaburkan dan diperebutkan oleh anak-anak yang mengikuti upacara ini. Setelah anak dikeluarkan dari dalam sangkar tadi, kemudian dimandikan di dalam jembangan (bak mandi) yang telah diisi air bunga setaman. Selanjutnya anak diberi pakaian serba baru dan perhiasan. Selanjutnya ialah upacara kenduri atau perayaan makan yang dipimpin langsung oleh sesepuh setempat, dengan adanya upacara kenduri itu maka berakhir pula upacara Tedhak siten. Dan sejak saat itu lah anak sudah diperbolehkan untuk menapak atau menginjakkan kakinya di tanah.

Langkah-langkah upacara tedhak siten sebagai berikut:

1. Anak yang bersangkutan dibimbing untuk berjalan dalam bahasa Jawa ditatah dengan kakinya untuk menginjak-injakkan kaki di atas jaddah yang berwarna-warni tadi.

2. Anak tersebut dinaikkan ke atas tangga yang terbuat dari batang tebu merah hati.

3. Anak dimasukkan ke dalam sangkar (kurungan) yang di dalamnya terdapat bokor berwarna kuning yang berisikan padi, gelang emas, cincin emas, alat-alat tulis, kapas dan berbagai macam barang yang bermanfaat dan berharga bagi sang anak kelak.

4. Bokor yang berisikan berbagai macam benda tersebut didekatkan kepada anak dengan maksud anak tersebut mengambil salah satu benda yang ada di dalam bokor tersebut.

5. Setelah anak mengambil salah satu benda dari dalam bokor misalnya gelang emas, pertanda anak yang bersangkutan kelak akan menjadi orang kaya. Jika yang diambil adalah alat-alat tulis, maka pertanda anak itu kelak akan menjadi orang yang sangat cerdas dan seterusnya.

6. Setelah selesai anak itu ditaburi beras kuning dengan bermacam-macam uang logam yang masih berlaku untuk diperbelanjakan, dan uang itu menjadi rebutan para undangan terutama anak-anak kecil yang melihat.

7. Kemudian anak tersebut dimandikan dengan air bunga setaman (melati, mawar, kenanga, kantil, pacar air dan sebagainya) supaya anak yang bersangkutan kelak dapat membawa nama baik bagi orang tua dan keluarganya.

8. Setelah dimandikan anak tersebut dikenakan busana serba baru agar menyenangkan orang tua sepanjang hidupnya.

Kekurangan dalam tradisi tedhak siten adalah dengan adanya symbol-simbol ritual yang diaktualisasikan oleh masyarakat Jawa, mengandung pengaruh asimilasi antar Hindu-Jawa, Budha-Jawa, dan Islam-Jawa yang menyatu padu dalam wacana kultural mistik. Asimilasi yang sering kali diasosiasikan oleh para pengamat sebagai sinkretisme tersebut juga terlihat dengan pembakaran kemenyan pada saat ritual mistik dilaksanakan, diyakini oleh masyarakat Jawa sebagai bagian dari penyembahan kepada Tuhan.

Adapun saat pembakaran kemenyan pada tradisi tedhak siten diniatkan dengan harapan sebagai tali pengikat keimanan. Hidupnya diharapkan sebagai cahaya yang 
terang, asapnya diharapkan sebagai bebauan surga, dan agar dapat diterima oleh Tuhan Yang Maha Kuasa. Tujuannya adalah agar kegiatan tersebut bermafaan untuk anak yang akan meniti kehidupannya nanti.

\section{Nilai-nilai Pendidikan Optimisme}

Kelebihan tradisi tedhak siten adalah dalam hal kenduri atau slametan bukan hanya acara makan-makan. Slametan kadang juga diiringi dengan upacara yang dipimpin langsung oleh sesepuh atau tokoh masyarakat setempat yang bisa memimpin doa, dengan harapan agar keluarga dan sang buah hati khususnya selalu mendapat keselamatan, diberkahi di dunia maupun akhirat, serta diterima dan bermanfaat bagi keluarga maupun mereka yang menghadirinya. Kenduri juga menjadi ajang mempererat tali silaturahmi: sanak keluarga, kerabat, dan lingkungan tetangga.

Hal ini senada dengan ajaran dalam agama Islam yang juga menekankan agar setiap orang mampu bersikap optimis terhadap diri dan lingkungannya dalam menggapai masa depan. Sesuai dengan surah Yunus ayat 6 sampai 7 yang sejatinya bahwa konsep harapan dapat meningkatkan kebaikan dan kehidupannya menjadi lebih baik. Rasa bahagia dengan Pendidikan karakter dan doa menjadi contoh untuk terus mengembangkan kemampuan diri dan jiwanya untuk terus memperbaharui dan memperbaiki kualitas perilakunya. Hal ini sesuai dengan fitrahnya bahwa teori behaviorisme juga menenakankan untuk terus melihat kondisi dan lingkungan sebagai bagian dalam pendiidkan. Karena sesuai dengan sunnatullah yang menginginkan bahwa sikap optimis itu dapat menjadikan suatu harapan dan akan tercapai pada masa datang. Harapan orang tua dalam tradisi ini setidaknya merupakan sebuah pondasi awal dengan rasa optimisme tinggi terhadap anaknya kelak agar memperbanyak karya dari berbagai bidang dan meninggalkan hal yang buruk dan mendapatkan kebahagiaan sejati.

Adat-istiadat yang terdapat dalam suatu masyarakat dengan masyarakat lainnya boleh diikuti selama itu tidak akan bertentangan dengan prinsip ajaran agama Islam. Dalam tradisi Jawa dapat pula dijumpai beberapa tradisi lain seperti, mitoni, puputan selapan, barokahan dan tedhak siten. Adapun ajaran Islam yang terkandung di dalam Tradisi Tedhak siten sebagai berikut:

1. Sedekah

Dalam proses tradisi tedhak siten adapun sebuah acara untuk memberikan makanan dan minuman kepada tetangga dan masyarakat sekitar. Dengan maksud untuk berbahi, dalam agama Islam hal tersebut dinamakan dengan shadaqah, sebagaimana firman Allah:

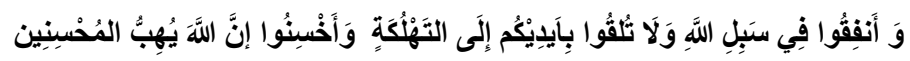

"Dan belanjakanlah (harta bendamu) dijalan Allah, dan janganlah kamu menjatuhkan dirimu dalam kebinasaan, dan berbuat baiklah, karena sesungguhnya Allah menyukai orang-orang yang berbuat baik"(Q.S AL-Baqarah: 195)

2. Syukur

Pada dasarnya tujuan dari tradisi tedhak siten ini merupakan rasa bersyukur seseorang kepada Allah SWT atas nikmat dan rezeki yang telah di berikan. Dengan diberikannya keturunan kepada ummatnya maka, akan menambah anggota keluarga yang bertujuan untuk mengungkapkan rasa bersyukur. Sebagaimana berfirman Allah:

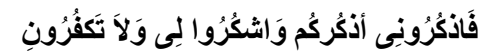

mahesainstitut@gmail.com 
"Maka ingatlah kepada-Ku, Aku pun akan ingat kepadamu dan bersyukur kepada$\mathrm{Ku}$, serta janganlah kamu mengingkari (nikmat)-Ku". (Q.S Al-Baqarah: 152) 3. Doa

Proses ini merupakan salah satu doa orang tua kepada Allah SWT untuk menyampaikan permohonan agar mendapatkan keselamatan dan kesejahteraan dalam mengasuh anak, serta memohon agar anak tersebut menjadi anak yang shaleh dan shalehah serta menjadi anak yang berguna baik untuk dirinya sendiri maupun untuk banyak orang. Allah berfirman:

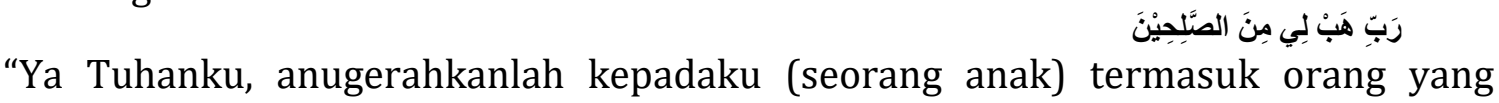
shaleh" (Q.S as-Saffat :100)

Secara utuh, kegiatan ritual ini dapat dilihat nilai filosofis dari beberapa proses dalam pelaksanaannya, yaitu:

a. Prosesi 'tedhak siten'

Prosesi tedhak siten diawali dengan membimbing anak untuk menapaki berbagai macam jaddah sebanyak 7 warna yang telah disusun. Jaddah (nasi ketan yang dilumatkan) ini terdiri dari tujuh warna yaitu merah, putih, hitam, biru, kuning, ungu dan merah jambu. Karena jaddah dibuat dari beras ketan, maka mudah lengket ditelapak kaki si anak. Anakpun harus bisa mengatasi kesulitan, dengan harapan semoga si anak kelak dapat mengataasi kesulitan hidup. Jaddah dibuat tujuh rupa, dalam bahasa Jawa tujuh ialah pitu yang mana bermakna semoga kelak dapat mengatasi kesulitan hidup dan selalu mendapat pitulungan atau pertolongan dari Yang Maha Kuasa. Jaddah di buat beraneka macam warna, menggambarkan bahwa kesulitan dan rintangan hidup itu tak terhitung jenis dan ragamnya.

Sajian untuk kenduri yang terdiri dari nasi tumpeng ayam dan lauk-pauk lainya serta kuluban (sayur dengan taburan kelapa yang sudah di olah) serta jajanan pasar, bubur merah, bubur putih dan bubur sengkolo. Jajanan pasar melambangkan Dalam kehidupan akan banyak berinteraksi dengan banyak orang dengan berbagai macam karakter sehingga si anak dapt dengan mudah bersosialisasi dengan msyarakat. Dan terdapat pula aneka pala pandem (umbi-umbian) yang mempunyai makna agar anak mempunyai sifat hidup andap asor atau tidak sombong.

b. Tangga yang terbuat dari tebu wulung

Tangga dibuat dari batang tebu wulung dengan jumalh anak tangga sebanyak tujuh buah. Tebu asal kata dari antebing kalbu berarti penuh tekad dan rasa percaya diri. Dipilih tebu wulung agar si anak kelak mempunyai tekad yang kuat dan percaya diri.

c. Kurungan ayam (sangkar) yang telah dihiasi dan didalamnya terdapat berbagai macam benda yang bisa anak pilih

Anak dibimbing dan disuruh untuk mengambil salah satu dari barang yang ada di dalam sangkar ayam adi, barang yang anak pilih merupakan gambaran dari kegemaran dan juga pekerjaan yang diminatinya kelak ketika dewasa. Kurungan ayam (sangkar) hanya sebagai gambaran yang di harapkan orang tua agar anak kelak cepat mandiri, dan bertanggung jawab pada kehidupannya. Dan dapat menyesuaikan diri dalam masyarakat luas dengan baik, dan mematuhi segala peraturan dan adat-istiadat setempat.

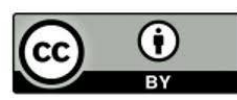


d. Sebar udhik-udhik (beras kuning) yang telah dicampur dengan uang logam untuk diperebutkan

Harapanya kelak agar anak jika dikaruniani rejeki cukup dapat mendermakan rejekinya kepada fakir miskin, prosesi ini meggambarkan agar anak kelak menjadi anak yang demrawan dalam lingkungannya.

e. Mandi dengan bunga setaman dan mengenakan baju serba baru

Tujuanya agar anak senantiasa tetap sehat, yang akan membawa nama harum bagi keluarganya, memiliki kehidupan yang layak, serta makmur dan berguna bagi lingkungannya kelak.

f. Penyerahan Nasi Tumpeng

Yang terakhir penggunaan tumpeng mengandung nilai kereligiusan, dimana sang anak diajarkan tentang Ketuhanan yang telah melimpahkan rahmat kepada keluarga dan lingkungan.

\section{SIMPULAN}

Tehdak Siten ini bertujuan untuk memohon kepada Yang Maha Kuasa agar diberikan keselamatan bagi sang anak untuk menjalani kehidupan berikutnya. Ajaran lainnya yaitu perwujudan rasa syukur manusia kepada karunia yang diberikan oleh Yang Maha Kuasa dalam pelaksanaan tradisi tedhak siten mengandung nilai yang dihidupi oleh orang Jawa, yaitu melalui upacara tersebut, orang tua menunjukkan kasih sayang yang besar kepada anak mereka. Mereka mengungkapkan harapan yang hakiki supaya anak tidak mengalami kesulitan dikemudian hari.

Nilai-nilai Pendidikan dengan prasangka optimisme dalam bentuk doa selalu dilakukan orang tua untuk masa depan anaknya. Sistem Pendidikan yang diajarkan dalam tradisi ini pada akhirnya memberikan sugesti pada orang tua dan anaknya agar mendapatkan Pendidikan yang baik dan mendapatkan kesuksesan pada masa akan datang. Kondisi ini searah dengan menggabungkan pendekatan behaviorisme dan humanistic dalam teori Pendidikan sesuai dengan fitrahnya sebagai manusia dan berkembang berdasarkan kemampuan dan doa dari orang tuanya.

\section{UCAPAN TERIMAKASIH}

Peneliti mengucapkan terimakasih sebesar-besarnya pada pihak Fakultas Syariah Universitas Islam Negeri Antasari, Banjarmasin yang telah membantu dalam pelaksanaan penelitian ini. Peneliti juga mengucapkan terimakasih sebesar-besarnya pada Dwi Devi Puspita Sari dan tim yang telah membantu menyusun data dan hasil observasi. Para sponsor desa dan ketua Program Studi Hukum Keluarga yang telah membantu dari berbagai aspek sebagai hibah dalam penyelesaian penelitian ini. Begitu juga teruntuk pada semua pihak yang tidak dapat disebutkan satu persatu dalam penyelesaian penelitian ini yang dilakukan selama tiga bulan dari bulan Juli hingga Oktober tahun 2019.

\section{DAFTAR PUSTAKA}

Anggraini, R. W., Sinaga, R. M., \& Wakidi, W. (2016). Tedhak siten Dalam Tradisi Masyarakat Jawa Desa Utama Jaya. Pesagi (Jurnal Pendidikan Dan Penelitian Sejarah), 4(1).

Batubara, K. S. (2017). Perbandingan Kearifan Lokal Hattanjou Iwai Pada Masyarakat Jepang Dan Tedhak siten Pada Masyarakat Jawa. 
Daud, A. (2000). Beberapa Ciri Etos Budaya Masyarakat Banjar. Banjarmasin: Iain Antasari.

Devi, N. S. S., \& Desain, F. S. R. D. (N.D.). Upacara Tedhak siten Di Desa Banyuanyar Kecamatan Banjarsari Kota Surakarta.

Djaya, T. R. (2020). Makna Tradisi Tedhak siten Pada Masyarakat Kendal: Sebuah Analisis Fenomenologis Alfred Schutz. Jurnal Ekonomi, Sosial \& Humaniora, 1(06), 21-31.

Fathurrozaq, M. (2019). Nilai-Nilai Pendidikan Islam Dalam Tradisi Tedhak siten Di Desa Senden Kecamatan Kampak Kabupaten Trenggalek (Phd Thesis). Universitas Islam Negeri Maulana Malik Ibrahim.

Hafidzi, A., \& Hayatunnisa, E. (2018). Kriteria Poligami Serta Dampaknya Melalui Pendekatan Alla Tuqsitu Fi Al-Yatama Dalam Kitab Fikih Islam Wa Adillatuhu. Syariah: Jurnal Hukum Dan Pemikiran, 17(1).

Humaidi, A. (2016). Nilai Budaya Dalam Lagu Banjar: Pernikahan, Mata Pencaharian, Dan Permainan Tradisional. Stilistika: Jurnal Bahasa, Sastra, Dan Pengajarannya, 1(1).

Lubis, F. (N.D.). Makna Upacara Tedhak siten Bagi Masyarakat Pendukungnya: Studi Deskriptif Tentang Makna Upacara Tedhak siten Bagi Masyarakat Jawa Di Desa Tanjung Jati Kecamatan Binjai Kabupaten Langkat.

Mokodenseho, S., \& Wekke, I. S. (2017). Toleransi Beragama Dan Pembelajaran Agama Islam. Prosiding, 1(1), 67-75.

Mursalim, B. (2019). Korelasi 'Urf Terhadap Makna Hermeneutika Simbolik Dan Agama Dalam Ritual Tedhak siten Adat. Al-Ahwal, 10(1).

Novita Sari, D. (2019). A Semiotical Analysis Of Tedak Siten Ceremony In Javanese Tradition (Phd Thesis).

Nugroho, E. R., \& Wahid, A. (2019). Perkawinan Tradisi Jujuran Dalam Adat Bugis Perantau Di Kutai Kartangera: Suatu Kajian Perbandingan Dengan Hukum Islam. Wajah Hukum, 3(2), 121-132.

Probowardhani, D. K., \& Sri Arfiah, S. H. (2016). Prosesi Upacara Tedhak siten Anak Usia 7 Bulan Dalam Tradisi Adat Jawa (Studi Kasus Di Desa Banyuagung Kecamatan Banjarsari Kota Surakarta Tahun 2016) (Phd Thesis). Universitas Muhammadiyah Surakarta.

Putra, W. (2013). Perkembangan Anak Ditinjau Dari Teori Mature Religion. Nadwa, 7(1), 1-19.

Schlehe, J. (2010). Anthropology Of Religion: Disasters And The Representations Of Tradition And Modernity. Religion, 40(2), 112-120. Doi: 10.1016/J.Religion.2009.12.004

Simanjuntak, B. A. (2016). Tradisi, Agama, Dan Akseptasi Modernisasi Pada Masyarakat Pedesaan Jawa (Edisi Revisi). Yayasan Pustaka Obor Indonesia.

Suharyanto, A. (2015). Pendidikan dan Proses Pembudayaan dalam Keluarga, JUPIIS: Jurnal Pendidikan Ilmu-Ilmu Sosial, 7 (2) (2015): 162-165.

Violetta Yuvinda Putri, L. (2017). Studi Komparatif Ritual Tedhak siten Di Jawa Dan Hatsu Tanjo Di Kyushu Jepang (Phd Thesis). Universitas Brawijaya.

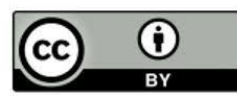

